\title{
ASSOCIATION OF FUNCTIONAL TRAIT VARIATION OF QUERCUS CASTANEA WITH TEMPERATURE AND WATER AVAILABILITY GRADIENTS AT THE LANDSCAPE LEVEL \\ RELACIÓN DE LA VARIACIÓN DE ATRIBUTOS FUNCIONALES DE QUERCUS CASTANEA CON GRADIENTES DE TEMPERATURA Y DISPONIBILIDAD DE AGUA A NIVEL DE PAISAJE
}

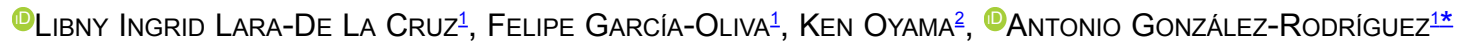 \\ ${ }^{1}$ Instituto de Investigaciones en Ecosistemas y Sustentabilidad, Universidad Nacional Autónoma de México Morelia, Michoacán, \\ México. \\ ${ }^{2}$ Escuela Nacional de Estudios Superiores, Unidad Morelia, Universidad Nacional Autónoma de México, Morelia, Michoacán, \\ México. \\ *Corresponding author: agrodrig@iies.unam.mx
}

\begin{abstract}
Background: Phenotypic variability of tree species is often associated to environmental factors. Quercus castanea is a Mexican red oak with a wide geographical and altitudinal distribution along contrasting environments. It is the most abundant oak species in the Cuitzeo basin, which is characterized by highly heterogeneous environmental conditions.

Hypothesis: We hypothesized that gradients in temperature, precipitation and soil characteristics across the distribution of $Q$. castanea within the Cuitzeo basin promote variability in functional traits related to the adjustment to differential water availability at a landscape level.

Studied species: Quercus castanea Née (Fagaceae).

Study site and years of study: Cuitzeo basin in Central Mexico. 2015-2016.

Methods: We quantified leaf chlorophyll concentration (CC), leaf area (LA), leaf thickness (LT), leaf mass per area (LMA) and the Huber value (HV) in 10 individuals from 22 populations of $Q$. castanea throughout the basin.

Results: Despite the relatively small geographical area $\left(4,000 \mathrm{~km}^{2}\right)$, our results revealed significant differentiation among populations in the studied functional traits. The strongest variation found was in LT, which was negatively correlated with precipitation seasonality. This pattern is opposite to previous reports on Mediterranean oaks but similar to tropical oaks and suggests that the combination with other traits such as leaf phenology is important in the response to water availability.

Conclusions: Significant functional differences exist among populations of $Q$. castanea separated by a few kilometers in the heterogenous landscape of the Cuitzeo basin. This species shows clearly sclerophyllous leaves, but leaf thickness varies to a considerable degree across populations.
\end{abstract}

Key words: climate gradient, leaf economic spectrum, plant morpho-physiological variation, Quercus.

\section{Resumen}

Antecedentes: La variación fenotípica de especies arbóreas con frecuencia se asocia a factores ambientales. Quercus castanea, un encino rojo mexicano de amplia distribución geográfica y altitudinal en ambientes contrastantes es el encino más abundante en la cuenca de Cuitzeo, caracterizada por presentar condiciones ambientales heterogéneas.

Hipótesis: Los gradientes de temperatura, precipitación y características del suelo en la cuenca de Cuitzeo promueven la variación en los atributos funcionales de $Q$. castanea relacionados con el ajuste a la disponibilidad de agua a nivel de paisaje.

Especie en estudio: Quercus castanea Née (Fagaceae).

Sitio de estudio y fechas: Cuenca de Cuitzeo, centro de México. 2015-2016.

Métodos: Cuantificamos la concentración de clorofila de la hoja (CC), el área foliar (LA), el grosor foliar (LT), la masa por área foliar (LMA) y el valor de Huber (HV) en 10 individuos de 22 poblaciones de Q. castanea distribuidas en la cuenca.

Resultados: A pesar del área geográfica pequeña $\left(4,000 \mathrm{~km}^{2}\right)$, nuestros resultados mostraron una diferenciación significativa en los atributos funcionales entre las poblaciones. La variación más marcada fue en LT, que se correlacionó negativamente con la estacionalidad de la precipitación. Este patrón es opuesto a resultados previos en encinos mediterráneos pero similar a encinos tropicales y sugiere que la combinación con otros atributos, como la fenología foliar, es importante en la respuesta a la disponibilidad de agua.

Conclusiones: Existen diferencias funcionales entre las poblaciones de Q. castanea separadas unos pocos kilómetros dentro de la cuenca. En particular el grosor de la hoja varía considerablemente.

Palabras clave: espectro económico foliar, gradiente climático, Quercus, variación en atributos funcionales. 
Variation in phenotypic traits is a fundamental attribute of natural populations and often reflects the linking of traits with geographical and climate variables across the range of a species (McKnow et al. 2014). In tree species, variation among populations in several fundamental functional traits is considerably influenced by water availability, which in turn depends on the amount and distribution of rainfall, soil physical properties, and the relationship between evaporation and transpiration (Souto et al. 2009, RamírezValiente et al. 2010, Cooper et al. 2018). Therefore, differences in water availability along the distribution of a species are expected to set contrasting selection pressures leading to local adaptation of populations, as has been shown in many tree species (Ramírez-Valiente et al. 2010, Aranda et al. 2015, Lind et al. 2107). However, the extent of local adaptation at fine spatial scales in long-lived tree species characterized by high rates of gene flow has not been sufficiently studied yet (Cavender-Bares \& RamírezValiente 2017). Alternatively, such species may face environmental challenges by maintaining high levels of within-population genetic variation or through phenotypic plasticity, particularly when single individuals may experience a range of conditions throughout the course of a long lifespan (Cavender-Bares \& Ramírez-Valiente 2017, Meireles et al. 2017).

The genus Quercus (oak species) is a very diverse group of tree species distributed in temperate, subtropical and tropical regions of the northern hemisphere, where it is considered one of the most important taxa of trees (Cavender-Bares 2016). This genus, along with others in the Fagaceae family are emerging as non-classical models to study adaptive variation, integrating ecology and evolution (Petit et al. 2013, Cavender-Bares 2019). Mexico is an important diversification center for the oaks, with about 161 species in total (32-40\% of the diversity in the world) and more than 100 endemics (Valencia-A 2004). Oaks constitute a very important group for understanding the factors that determine phenotypic variability, due to their particularly high levels of variation at different levels, that is, among species, among populations, within populations and within individuals (Uribe-Salas et al. 2008, Hernández-Calderón et al. 2014, García-Nogales et al. 2016).

Plant functional traits are measurable characteristics that influence performance or fitness and are assumed to reflect evolutionary responses to external conditions and can frequently refer to ecological factors changing along a gradient (Lavorel et al. 2007). Research on different oak species has revealed functional variation related to leaf traits, phenology, and growth rates associated to altitudinal, latitudinal, water availability or temperature gradients (Bruschi 2010, Hernández-Calderón et al. 2013, RamírezValiente et al. 2017). This variation has been explained as resulting from strategies to avoid or tolerate different types of environmental stress, allowing oak species to develop under a wide range of environmental conditions and resource availability. However, most of these studies have been conducted at broad geographical scales, and little is known about how functional traits vary among tree populations at finer spatial scales such as the landscape level.

Quercus castanea is a Mexican red oak with a wide geographical and altitudinal distribution that occupies contrasting environments, with populations in the Sierra Madre Occidental, the Central Plateau, the Trans-Mexican Volcanic Belt, and the Sierra Madre del Sur (Valencia-A 2004). It is a dominant element in temperate forests and mountain cloud forests and is frequently found in perturbed areas with a xerophytic shrub type of vegetation (ValenciaCuevas et al. 2015). Therefore, $Q$. castanea represents a suitable species to study patterns of phenotypic variation in response to environmental factors at a landscape scale, despite potentially very high gene flow even in a fragmentation scenario (Herrera-Arroyo et al. 2013, Oyama et al. 2017).

In this study, we hypothesized that gradients in temperature, precipitation and soil characteristics across the distribution of $Q$. castanea within the Cuitzeo basin promote variability in functional traits related to the adjustment to differential water availability. We focused on leaf traits that have been considered easy and inexpensive to measure in a standardized manner (leaf chlorophyll concentration, leaf area, leaf mass per area, leaf thickness and the Huber value) but that capture the general patterns of plant functional responses to environmental gradients (Wright et al. 2004, Lavorel et al. 2007). According to these previous generalizations, we expected $Q$. castanea individuals to have a higher Huber value and smaller, thicker leaves with a higher mass per area in the parts of the basin with higher temperature and lower precipitation. Particularly, the objectives were: i) to evaluate the amount and patterns of variation in this set of functional traits across $Q$. castanea populations at a landscape level and ii) to determine significant associations between functional traits and environmental variables.

\section{Materials and methods}

Study site and sampling procedure. This study was conducted in the basin of Lake Cuitzeo. It has an area of $4,026 \mathrm{~km}^{2}$ and is located at $19^{\circ} 30^{\prime}-20^{\circ} 05^{\prime} \mathrm{N}$ and $100^{\circ} 35^{\prime}$ - $101^{\circ} 30^{\prime} \mathrm{W}$ in the Trans-Mexican Volcanic Belt in the northern part of Michoacan state and the southern part of Guanajuato state (Figure 1). Climate in the basin is temperate with a marked rainy season during summer months (June to September). There is a significant climate gradient, with precipitation increasing and temperature decreasing from north to south and with altitude (Mendoza et al. 2006). The topography and soils of the study area are 


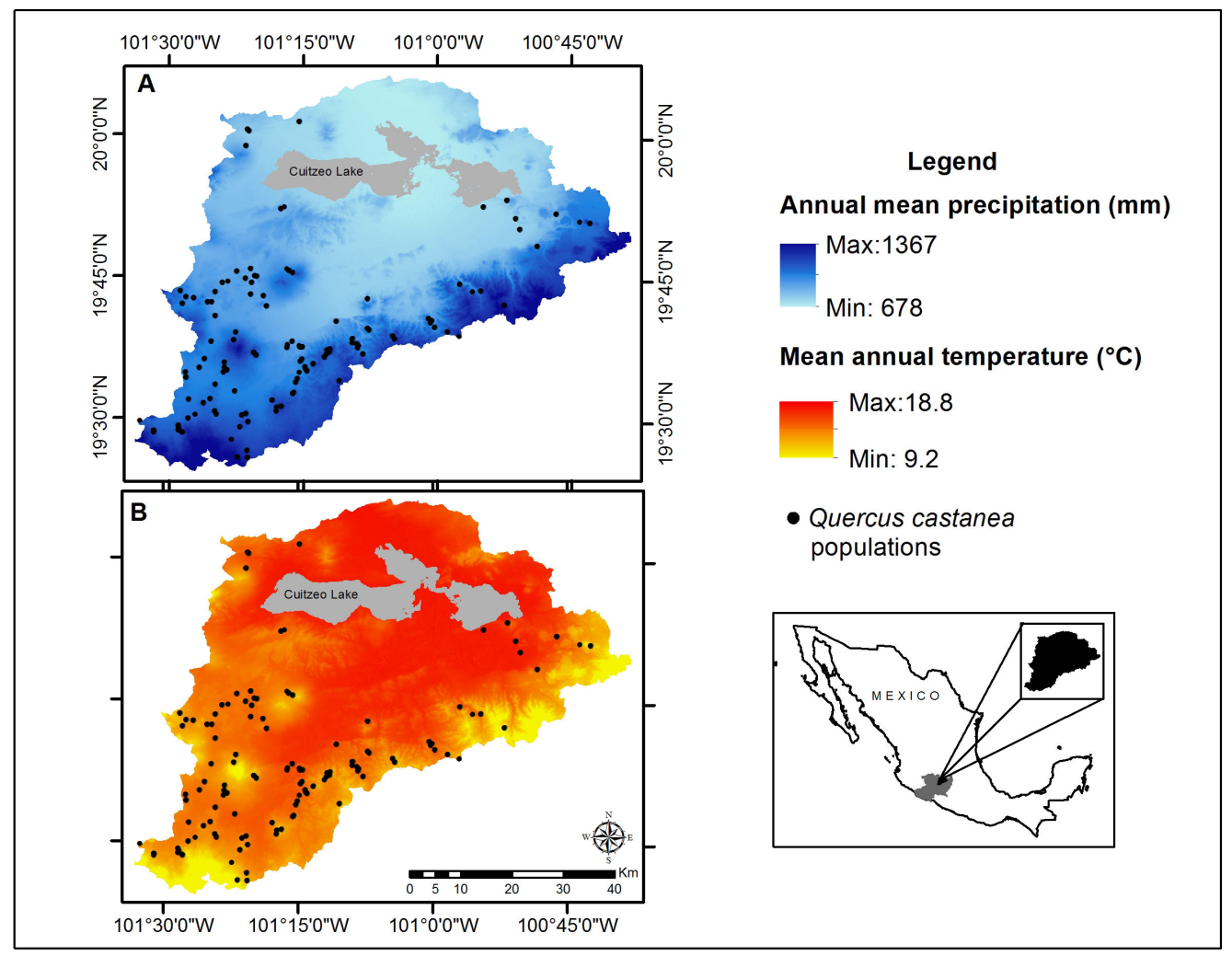

Figure 1. Climate gradients in the Cuitzeo lake basin and the distribution of the $Q$. castanea populations; a) annual mean temperature, b) annual mean precipitation.

product of the volcanic activity of the Quaternary. The dominant soil groups are vertisols, luvisols, leptosols, acrisols and andosols (Mendoza et al. 2006, ChávezVergara et al. 2014).

Quercus castanea grows throughout the Cuitzeo basin, except in the northeastern portion (Aguilar-Romero et al. 2016). In the study region, populations can be found between 2,000 and 2,800 m (Herrera-Arroyo et al. 2013). Twenty-two populations were chosen for sampling, mostly covering the distribution of the species within the Cuitzeo basin (Table S1, Figure 2). At each population, 10 randomly chosen adult trees separated by at least $20 \mathrm{~m}$ from each other were sampled by taking four haphazardly selected sun-exposed branches, with terminal twigs with at least 10 matures leaves with no visible damage, at heights between 2 and $5 \mathrm{~m}$. Only in population 10, fewer trees were collected (6) because of their low availability.

Functional traits. In each individual tree, we measured the following functional traits: leaf chlorophyll concentration (CC), leaf area (LA), leaf mass per area (LMA), leaf thickness (LT) and Huber value (HV, the sapwood cross section area divided by the leaf area distal to the stem) (Tyree \& Ewers 1991). Studying these functional traits is relevant because they are adaptive and vary along environmental gradients in many plant species (Auger \& Shipley 2013, Rosbakh et al. 2015, Cochrane et al. 2016). CC directly influences the photosynthetic capacity of plants (Croft et al. 2017). LA is important in the balance of water and energy of the plant and usually smaller leaves are associated with high radiation, heat-, cold- or drought-stress (Cornelissen et al. 2003). LMA is positively related to the investment in structural defenses and with leaf lifespan and usually higher values of LMA occur in environments with higher resources stress. LT is associated with photosynthetic rates per unit of leaf area and is usually correlated positively with mean temperature and with solar radiation (Niinemets 2001). Finally, HV is higher in more arid sites (Carter \& White 2009).

Leaf chlorophyll concentration was measured in the field using the Minolta Soil Plant Analysis Development (SPAD-502) chlorophyll meter (Markwell et al. 1995) in three randomly chosen leaves per individual. For the other traits, fully developed leaves without damage were dried at $55{ }^{\circ} \mathrm{C}$, weighed in an analytical balance, and lamina thickness measured in a portion of the leaf without veins using a Mitutoyo Absolute digital caliper (model 500-172-20) with a $0.01 \mathrm{~mm}$ precision. Leaves were then imaged with a flatbed high resolution scanner (Epson V700), and the area of each leaf was determined 


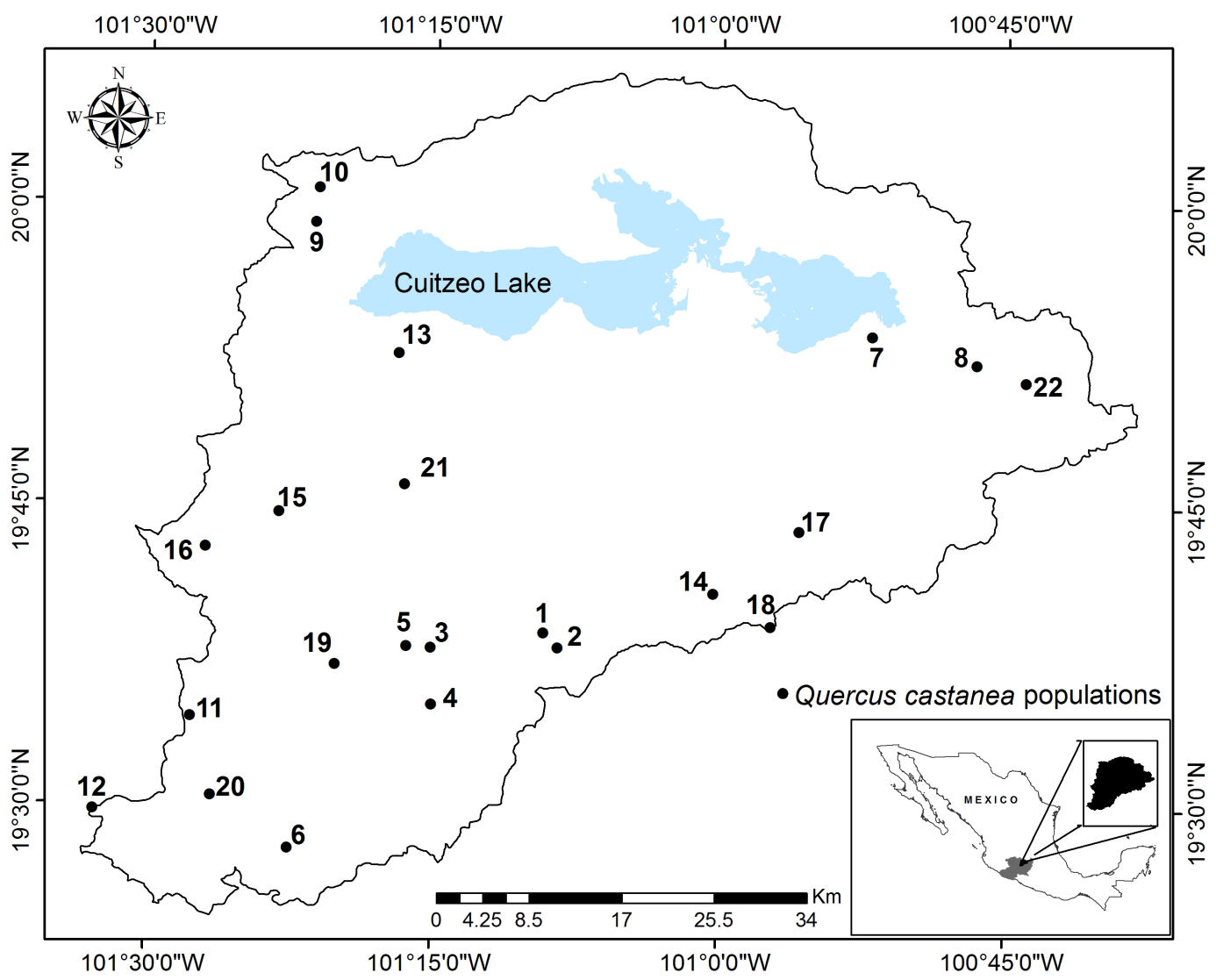

Figure 2. Cuitzeo lake basin and the distribution of the 22 Q. castanea populations sampled.

using the ImageJ software (Rasband 2010). Leaf mass per area was calculated as the ratio between dry mass and leaf area values. These traits were measured in ten randomly chosen leaves per tree. For the Huber value, three twigs per tree were selected. The leaf area was determined by digitalizing all the twig leaves with the high-resolution flatbed scanner and summing their individual areas. The area of the sapwood was determined from the diameter of cross sections of the leafless twigs measured with the digital caliper after removing the bark. This trait was determined for three twigs per individual.

Geographic and environmental variables. Spatial coordinates and altitude of each sampling population were recorded using a global positioning system (GPS) unit (Table 1S). Soil type for each population was extracted from a soil surface (Cabrera-González et al. 2010) using GIS Arc View ver. 3.3 (ESRI 1999). To determine soil water holding capacity, three soil samples were taken in different random directions (keeping a minimum angle of $70^{\circ}$ between samples) one meter away from the main trunk of each oak tree sampled using a soil core sampler. In the laboratory, soil samples were dried in an oven at $70{ }^{\circ} \mathrm{C}$ for 3 days.
Subsequently, $10 \mathrm{~g}$ of dry soil from each sample were weighted, then wetted to field capacity and weighted again. Soil water holding capacity (WHC) was calculated as follows:

$\mathrm{WHC}=($ weight of wet soil - weight of dry soil $/$ weight of dry

$$
\text { soil) } \times 100
$$

This variable was determined as an average of values of the three soil samples per oak tree and then an average value per population was obtained.

To characterize the climate at each population, 19 bioclimatic variables derived from monthly precipitation and temperature values (period 1910-2009) were extracted at 30 arc seconds and downscaled using a digital elevation model at $30 \mathrm{~m}$ of resolution (Cuervo-Robayo et al. 2014, Correa-Ayram et al. 2017). Nineteen climatic variables were finally obtained for each population using GIS Arc View v3.3 (ESRI 1999).

Data Analysis. The significance of the differences among populations for each functional trait were evaluated through one-way analyses of variance (ANOVA) using average values of individual trees. To determine how the total 
variance for each functional trait is partitioned among populations, among trees within populations, and within trees, we estimated the variance components using the restricted maximum likelihood (REML) method. Residual variation was considered to correspond to differences among leaves within trees. In this analysis the full database with individual leaf values was used. A stepwise canonical discriminant analysis (CDA) using individual tree averages for each functional trait was performed to further determine which functional traits have the highest variation among the populations sampled. Finally, to evaluate the degree of association among the different functional traits, a pairwise correlation analysis was performed. These analyses were carried out in JMP 8 (SAS Institute, Cary, North Carolina).

The associations between the population mean values of each functional trait and the environmental variables at each sampling population were evaluated with Spearman's correlation analyses. Before conducting the correlation analyses, redundancy was reduced among the environmental variables by assessing pairwise correlations and discarding the more specific variable in each pair of highly correlated variables $(r \geq 0.8)$. The included environmental variables were soil water holding capacity (WHC), annual mean temperature (B1), mean diurnal range (B2), isothermality (B3), minimum temperature of the coldest month (B6), temperature annual range (B7), annual precipitation (B12), precipitation of the driest month (B14), precipitation seasonality (B15) and precipitation of the driest quarter (B17). The JMP 8 program was used in these analyses (SAS Institute, Cary, North Carolina).

To separate the effects of spatial distance and environmental variables on phenotypic variation we performed a Redundancy Analysis (RDA) (Van den Wollenberg 1977), which is a constrained ordination method analogous to linear regression for datasets with multiple dependent and multiple independent variables. Three separate RDAs were conducted: (1) a full model with environmental and geographic variables (latitude and longitude of the populations) as explanatory variables; (2) a partial RDA (pRDA1) where we removed geographic variables (i.e., a pure environmental model) and (3) a partial RDA (pRDA2) where we removed environmental variables (i.e., a pure geographic model). We then used variance partitioning to calculate the proportion of variation explained by the independent contributions of environmental and geographic variables and their joint effect (Borcard et al. 1992, Peres-Neto et al. 2006). The significance of each RDA model was calculated using a permutation test with 1,000 permutations. We calculated the adjusted coefficient of multiple determination $\left(R_{\text {adj }}^{2}\right)$ for all models (Peres-Neto et al. 2006). Data of the five functional traits were used as the response variables in the three RDAs.
The five variables were $\log _{10}$-transformed to correct for skew, and then centered and standardized before the RDA analysis. The explanatory variables included eight of the environmental variables described above, but we excluded isothermality (B3) because centering and standardizing this variable resulted mostly into zero values. Explanatory variables also included spatial variables defined using principal coordinates of neighborhood matrices (PCNM), which were calculated from the geographic coordinates in decimal degrees (Dray et al. 2006). We retained half of the PCNM variables with positive eigenvalues, as has been suggested by some authors (Manel et al. 2012, Fitzpatrick \& Keller 2015), which were seven in our case. Calculation of PCNM, RDA, test for the significance and adjusted coefficient of multiple determination of the models were performed in $\mathrm{R}$ ( $\underline{\mathrm{R} \text { Core Team 2016) }}$, using the 'vegan' 2.3-0 package (Oksanen et al. 2015).

\section{Results}

One-way ANOVAs indicated highly significant differences among populations for the five functional traits evaluated (Table 1). However, total variance was partitioned differently depending on the trait. LT showed the largest variation among populations $(43.9 \%)$ while for the other four traits variation among trees within populations and leaves within trees accounted for the largest proportion of the variance (Table 2).

Table 1. Results of the one-way ANOVAs for the comparison of five functional traits among 22 populations of $Q$. castanea in the Cuitzeo basin, Michoacan state, Mexico.

\begin{tabular}{lcc}
\hline Trait & $\boldsymbol{F}_{21,186}$ & \multicolumn{1}{c}{$\boldsymbol{P}$} \\
\hline Chlorophyll concentration & 5.33 & $<0.0001$ \\
Leaf area & 6.08 & $<0.0001$ \\
Leaf mass per area & 3.4 & $<0.0001$ \\
Leaf thickness & $13.94<0.0001$ \\
Huber value & $4.44<0.0001$ \\
\hline
\end{tabular}

The stepwise canonical discriminant analysis indicated that the variable that contributes more importantly to differentiate populations is LT, followed by LMA, LA, CC and HV. The two first canonical discriminant functions allowed highly significant discrimination among populations (Wilks' lambda $=0.048 ; P<0.0001$ ) and explained 71.2 and $16.13 \%$ of the variation, respectively (Table 3). The variables that contributed more strongly to the first canonical function were LT and LMA, while LA, $\mathrm{CC}$ and $\mathrm{HV}$ contributed to the second canonical function.

We found moderate but significant positive correlations of leaf mass per area with leaf thickness and with the Huber 
value (Table 4). Chlorophyll content had positive weak correlations with leaf mass per area and the Huber value. In contrast, negative correlations were observed between leaf mass per area and leaf area, between chlorophyll content and leaf thickness and between the Huber value and leaf area (Table 4).

According to the Spearman's correlation analyses, LMA had a significant negative correlation with annual mean temperature $\left(r_{\mathrm{s}}=-0.5 ; P=0.017\right)$ and a positive correlation with isothermality $\left(r_{\mathrm{s}}=0.5 ; P=0.016\right)$. $\mathrm{CC}$ and $\mathrm{HV}$ were also positively related to isothermality $\left(r_{\mathrm{s}}=0.48 ; P=0.02\right.$ and $r_{\mathrm{s}}=0.43 ; P=0.04$, respectively), while LT was negatively correlated with precipitation seasonality $\left(r_{\mathrm{s}}=-0.6 ; P=0.003\right)$.

The full RDA model for the combined effect of geographic and climatic explanatory variables on functional trait variation was significant $(P=0.001)$. The pRDA1 for the association between environmental variables and functional trait variation while controlling for geographic effects was also significant $\left(P=0.001, R_{\text {adj }}^{2}=13.9 \%\right)$

Table 2. Restricted maximum likelihood (REML) variance components (as percentage of total variation) for five functional traits for Q. castanea in the Cuitzeo basin. Variation among populations, among individuals within populations and within individuals (residual variance) was considered.

\begin{tabular}{lccc}
\hline \multicolumn{1}{c}{ Trait } & Population & Individuals within populations & Residual \\
\hline Chlorophyll concentration & 24.25 & 43.74 & 32 \\
Leaf area & 20.7 & 34.73 & 44.56 \\
Leaf mass per area & 7.2 & 25.8 & 67 \\
Leaf thickness & 43.9 & 27.98 & 28.11 \\
Huber value & 16.4 & 30.53 & 53.06 \\
Average & 22.49 & 32.56 & 44.95 \\
\hline
\end{tabular}

Table 3. Results of the stepwise canonical discriminant analysis for functional traits in $Q$. castanea.

\begin{tabular}{lcc}
\hline & \multicolumn{1}{c}{ Canonical 1 } & Canonical 2 \\
\hline Eigenvalue & 4.36 & 0.99 \\
Percent (\%) & 71.2 & 16.13 \\
Cumulative percent (\%) & 71.2 & 87.33 \\
Functional trait & Scoring coefficients \\
CC & 0.02 & 0.14 \\
LMA & 767.15 & -57.96 \\
LA & 0.07 & -0.167 \\
LT & -63.5 & 9.86 \\
HV & -0.05 & 0.152 \\
\hline mass per area, LA = leaf area, LT = leaf thickness, HV $=$ Huber value
\end{tabular}

Table 4. Pairwise correlations among functional trait variables.

\begin{tabular}{lllllll} 
& \multicolumn{2}{l}{ Variables $\mathbf{C C}$} & LA & LT & HV & LMA \\
\hline CC & 1.0000 & & & \\
LA & -0.1232 & 1.0000 & & \\
LT & $-0.1362 *$ & 0.0520 & 1.0000 & \\
HV & $0.1944 * *$ & $-0.4651 * *$ & 0.0368 & 1.000 \\
LMA & $0.1570 *$ & $-0.2934 * *$ & $0.5229 * *$ & $0.4640 * * 1.0000$ \\
\hline
\end{tabular}

$\mathrm{CC}=$ chlorophyll concentration, $\mathrm{LA}=$ leaf area, $\mathrm{LT}=$ leaf thickness, $\mathrm{LMA}=$ leaf mass per area, $\mathrm{HV}=$ Huber value $* P<0.05 ; * * P<0.01$ 
(Table 5). In this analysis, the most important variables were annual precipitation (B12) and precipitation of the driest quarter (B17), followed by minimum temperature of the coldest month (B6), annual mean temperature (B1), mean diurnal range (B2), temperature annual range (B7) and precipitation of the driest month (B14) (Table S2). The pRDA2 indicated that geography alone explained a slightly higher proportion of functional trait variation $(P=0.001$, $\left.R_{\text {adj }}^{2}=18.4 \%\right)$. Finally, joint climate and geography accounted for $71.9 \%$ of the variation (Table 5).

\section{Discussion}

Our analysis at a landscape scale showed significant variation among populations of $Q$. castanea in the functional traits studied. Furthermore, we identified the environmental variables with the largest influence on these functional traits at this spatial scale. It is widely acknowledged that leaf area, leaf mass per area, leaf thickness and Huber value are adaptive and vary according to the environment. These traits are related to water use efficiency and tolerance to temperature and water stress (Westoby et al. 2002, Wright et al. 2004, Lohbeck et al. 2013), and leaf mass per area and leaf thickness are functional traits within the leaf economic spectrum (LES) (De La Riva et al. 2016).

Variation among populations. In comparison to other oak species studied across the world, we found that $Q$. castanea showed a high leaf mass per area (range 134-183 $\mathrm{g} \mathrm{m}^{-2}$ ), relatively low leaf areas $\left(9.38-18.62 \mathrm{~cm}^{2}\right)$ and intermediate leaf thickness (0.11-0.24 mm) (Table S3). The value of leaf mass per area is situated at the higher end of values reported for oaks, and comparable to values found in evergreen Mediterranean and evergreen arid species (Gil-Pelegrín et al. 2017). According to Flexas et al. (2014) a leaf mass per area value higher than $120 \mathrm{~g} \mathrm{~m}^{-2}$ indicates a true sclerophyllous species. Leaf thickness was within the range of mean values reported for deciduous temperate and evergreen arid oak species. In turn, leaf area was higher than for Mediterranean and arid evergreen species, but lower than for tropical and temperate evergreen and deciduous species (Gil-Pelegrín et al. 2017). These three traits (leaf area, leaf thickness, leaf mass per area) showed highly significant variation among the sampled populations of $Q$. castanea even though, except for leaf thickness, variation among trees within populations was higher, suggesting the importance of microenvironmental factors (or other unaccounted factors) in determining intraspecific functional trait variation.

Leaf mass per area has been considered a key leaf functional trait for plants (Wright et al. 2004, Poorter et al. 2009). In $Q$. castanea populations, leaf mass per area showed a positive correlation with leaf thickness and a negative correlation with leaf area (Table 4). However, leaf thickness was the trait that showed the lower intraindividual and intra-population variation and the higher among-population variation (Table 2), suggesting its importance in the adjustment of $Q$. castanea to the environment.

In a previous study within the Cuitzeo basin, AguilarRomero et al. (2017) had compared water-use strategies among nine oak species (including $Q$. castanea) distributed along an aridity gradient. In that study, species from more arid areas had more deciduousness and a higher instantaneous water-use efficiency, while their more humid counterparts had less deciduousness and a xylem that was more resistant to embolisms, suggesting a trade-off between the xylem vulnerability to embolism and deciduousness. In that study, $Q$. castanea was characterized as occupying an intermediate position along the aridity gradient, with a brevideciduous phenology and also intermediate values (in relation to the other eight species) of wood density, water use efficiency, Huber value and xylem resistance to embolism (Aguilar-Romero et al. 2017). However, the breadth of the environmental niche of each species and its correspondence with the degree of intraspecific variability in functional traits was not considered. As we have seen in this study, such evaluation is critical, since some traits may exhibit even higher intraspecific than interspecific variation. For example, both in greenhouse grown seedlings and in

Table 5. Results of redundancy analysis (RDA) for the association between functional trait variation, geography and climate variables for Quercus castanea populations. Two partial analysis are shown pRDA1 (effect of climatic variables while controlling for geographic effects) and pRDA2 (effect of geographic distribution while controlling for climatic variation). The proportion of variance explained by both geographic and climate effects is also indicated (joint climate/geography). Proportion constrained corresponds to the partitioned variance relative to the constrained variance of the full RDA model.

\begin{tabular}{lcccc}
\hline & Inertia & Proportion & $\boldsymbol{R}_{\text {adj }}^{2}$ & $\boldsymbol{P}$ \\
\hline Full model: geography and climate (constrained variance) & 5.000 & 1 & 0.28 & 0.001 \\
Pure climate (pRDA1) & 0.5917 & 0.1183 & 0.13 & 0.001 \\
Pure geography (pRDA2) & 0.8136 & 0.1627 & 0.18 & 0.001 \\
Joint climate/geography & 3.5947 & 0.7190 & -0.04 & NA \\
\hline
\end{tabular}


adult trees from the field, Ramírez-Valiente et al. (2015) found higher differences among populations of the tropical oak $Q$. oleoides than among species within the same clade (Virentes, the live oaks), for various functional traits in response to drought. Therefore, the extent and ratio of intraversus interspecific variation, and their relationship with the niche breadth of the species and their coexistence within communities is still an open question (Cavender-Bares et al. 2004).

Association with environmental variables. Even at the relatively fine spatial scale of the Cuitzeo basin, we were able to define several significant associations of the traits measured with environmental variables. The strongest pairwise association was a negative correlation between leaf thickness and precipitation seasonality, meaning that leaves are thinner at populations where precipitation is more seasonal (i.e. there are more marked dry and wet periods). In turn, leaf mass per area had a positive correlation with isothermality and negative correlation with annual mean temperature, and the Huber value had a positive correlation with isothermality. Higher Huber values mean that the tree produces more wood per unit of leaf area, a characteristic that suggests an improvement in its water and nutrient storage capacity (Callaway et al. 1994) and that reduces the vulnerability to embolism of the xylem (Tyree \& Dixon 1986).

In turn, the multivariate RDA identified annual precipitation (B12) and precipitation of the driest quarter (B17) as the most important environmental variables influencing functional trait variation of $Q$. castanea in the Cuitzeo basin, with also a considerable contribution of precipitation of the driest month (B14). Overall, these results indicate that leaves of $Q$. castanea are more sclerophyllous (i.e. have higher leaf mass per area) in sites that are cooler and less seasonal in precipitation and temperature variation, and less sclerophyllous in more seasonal and warmer sites. Previously, sclerophylly has been considered an adaptation to arid environments across biomes (Niinemets 2001). At the intraspecific level, leaf mass per area has been shown to increase with aridity in Mediterranean oaks such as $Q$. ilex and $Q$. coccifera (Peguero-Pina et al. 2016). However, the opposite pattern has been shown in populations of $Q$. oleoides that tended to have more sclerophyllous leaves in more mesic areas (Ramírez-Valiente et al. 2015, 2017). The authors suggested that this counterintuitive result is due to phenological differences: populations from mesic populations maintain leaves for longer time during the dry season and therefore maintain function with increasing water stress (CavenderBares \& Ramírez-Valiente 2017). Therefore, selection has favored an increase in deciduousness (and less investment in tissue construction) with increasing dry season severity in this tropical oak species, contrasting with Mediterranean species that are limited by both cold winters and dry summers (Cavender-Bares \& Ramírez-Valiente 2017). Therefore, $Q$. castanea follows a pattern resembling more a tropical than a Mediterranean species. We hypothesize that phenological patterns (i.e. degree of deciduousness) in this species should be negatively associated with leaf mass per area along populations in the Cuitzeo basin, but this should be evaluated in further studies.

We conclude that, while previous studies have considered functional variation in oak species at a whole-range level, we have shown that significant functional differences exist among populations of $Q$. castenea separated by a few kilometers in the heterogenous landscape of the Cuitzeo basin. This species shows clearly sclerophyllous leaves but leaf thickness varies to a considerable degree across populations in association with precipitation seasonality, indicating that the temporality of water availability represents a significant environmental pressure for this oak species. Whether the observed functional variation is due to local adaptation, plasticity or a combination of both will be clarified in ongoing common garden and landscape genomics studies.

\section{Acknowledgements}

The authors thank Goretty Mendoza, Tamara Ochoa, Jesús Llanderal, Gonzalo Contreras, Oscar De Luna and Ricardo Gaytán for field assistance, and the kind help of Rodrigo Velázquez during soil water holding capacity determination in the lab. Comments by two anonymous reviewers are greatly appreciated. This paper constitutes a partial fulfillment of the Graduate Program in Biological Sciences of the National Autonomous University of Mexico (UNAM). L. I. Lara-De La Cruz acknowledges the scholarship and financial support provided by the National Council of Science and Technology (CONACyT) (215407). This work was supported by Dirección General de Asuntos del Personal Académico (DGAPA)-Programa de Apoyo a Proyectos de Investigación e Innovación Tecnológica (PAPIIT) IV201015 and IN207417 and CONACyT 240136

\section{Supplemental data}

Supplemental material for this article can be accessed here: $\underline{\text { https://doi.org/10.17129/botsci.2449 }}$

\section{Litrature Cited}

Aguilar-Romero R, García-Oliva F, Pineda-García F, Torres I, Peña-Vega E, Ghilardi A, Oyama K. 2016. Patterns of distribution of nine Quercus species along an environmental gradient in a fragmented landscape in central Mexico. Botanical Sciences 94: 471-482. DOI: https://doi.org/10.17129/botsci.620 
Aguilar-Romero R, Pineda-García F, Paz H, GonzálezRodríguez A, Oyama K. 2017. Differentiation in the water-use strategies among oak species from central Mexico. Tree Physiology 37: 915-925. DOI: https:// doi.org/10.1093/treephys/tpx033

Aranda I, Cano FJ, Gascó A, Cochard H, Nardini A, Mancha JA, López R, Sánchez-Gómez D. 2015. Variation in photosynthetic performance and hydraulic architecture across European beech (Fagus sylvatica L.) populations supports the case for local adaptation to water stress. Tree Physiology 35: 34-46. DOI: https:// doi.org/10.1093/treephys/tpu101

Auger S, Shipley B. 2013. Inter-specific and intra-specific trait variation along short environmental gradients in an old-growth temperate forest. Journal of Vegetation Science 24: 419-428. DOI: https://doi.org/10.1111/ j.1654-1103.2012.01473.x

Borcard D, Legendre P, Drapeau P. 1992. Partialling out the spatial component of ecological variation. Ecology 73: 1045-1055. DOI: https://doi.org/10.2307/1940179

Bruschi P. 2010. Geographical variation in morphology of Quercus petraea (Matt.) Liebl. as related to drought stress. Plant Biosystems 144: 298-307. DOI: https:// doi.org/10.1080/11263501003672462

Cabrera-González A, Medina-Orozco LE， SánchezEspinosa F, Alcalá-de Jesús M, Ayala-Gómez JM. 2010. Los suelos de la Cuenca de Cuitzeo. In: Cram S, Israde I, Mendoza M, Sommer I, Galicia L, eds. Atlas de la Cuenca del Lago Cuitzeo: un análisis de la geografía del lago y su entorno socioambiental. Universidad Nacional Autónoma de México y Universidad Michoacana de San Nicolás de Hidalgo, pp 44-47. ISBN: 978-607-02-1830-9

Callaway RM, DeLucia EH, Schlesinger WH. 1994. Biomass allocation of montane and desert ponderosa pine: an analog for response to climate change. Ecology 75: 1474-1481. DOI: https://doi.org/10.2307/1937470

Carter JL, White DA. 2009. Plasticity in the Huber value contributes to homeostasis in leaf water relations of a mallee Eucalypt with variation to groundwater depth. Tree Physiology 29: 1407-1418. DOI: https://doi.org/ 10.1093/treephys/tpp076

Cavender-Bares J. 2016. Diversity, distribution and ecosystem services of the North American oaks. International Oaks 27: 37-49.

Cavender-Bares J. 2019. Diversification, adaptation, and community assembly of the American oaks (Quercus), a model clade for integrating ecology and evolution. New Phytologist 221: 669-692. DOI: https://doi.org/10.1111/ nph. 15450
Cavender-Bares J, Kitajima K, Bazzaz FA. 2004. Multiple trait associations in relation to habitat differentiation among 17 Floridian oak species. Ecological Monographs 74: 635-662. DOI: https://doi.org/10.1890/03-4007

Cavender-Bares J, Ramírez-Valiente JA. 2017. Physiological evidence from common garden experiments for local adaptation and adaptive plasticity to climate in American Live Oaks (Quercus Section Virentes): Implications for conservation under global change. In: Gil-Peregrin E, Peguero-Pina JJ, SanchoKnapik D, eds. Oaks Physiologycal Ecology. Exploring the Functional Diversity of Genus Quercus L. Tree Physiology. eISBN 978-3-319-69099-5

Chávez-Vergara B, Merino A, Vázquez-Marrufo G, GarcíaOliva F. 2014. Organic matter dynamics and microbial activity during decomposition of forest floor under two native neotropical oak species in a temperate deciduous forest in Mexico. Geoderma 235: 133-145. DOI: https:// doi.org/10.1016/j.geoderma.2014.07.005

Cochrane A, Hoyle GL, Yates CJ, Neeman T, Nicotra AB. 2016. Variation in plant functional traits across and within four species of Western Australian Banksia (Proteaceae) along a natural climate gradient. Austral Ecology 41: 886-896. DOI: https://doi.org/10.1111/ aec. 12381

Cooper CE, Vogel JG, Muir JP, Moore GW. 2018. Leaf functional trait responses to changes in water status differ among three oak (Quercus) species. Plant Ecology 219: 1463-1479. DOI: htts://doi.org/10.1007/ s11258-018-0894-3

Cornelissen JHC, Lavorel S, Garnier E, Díaz S, Buchmann N, Gurvich DE, Reich PB, Steege HT, Morgan HD, Van Der Heijden MGA, Pausas JG, Poorter. 2003. A handbook of protocols for standarized and easy measurement of plant functional traits worldwide. Australian Journal of Botany 51: 335-380. DOI: https:// doi.org/10.1071/BT02124

Correa-Ayram CA, Mendoza ME, Etter A, Pérez-Salicrup DR. 2017. Potential distribution of Mountain Cloud Forest in Michoacán, México: Priorization for conservation in the context of landscape connectivity. Environmental Management 60: 86-103. DOI: https:// doi.org/10.1007/s00267-017-0871-y

Croft H, Chen JM, Luo X, Barlett P, Chen B, Staebler RM. 2017. Leaf chlorophyll content as a proxy for leaf photosynthetic capacity. Global Change Biology 23: 3513-3524. DOI: https://doi.org/10.1111/gcb.13599

Cuervo-Robayo AP, Téllez-Valdés O, Gómez-Albores MA, Venegas-Barrera CS, Manjarrez J, Martínez-Meyer E. 
2014. An update of high-resolution monthly climate surfaces for Mexico. International Journal of Climatology 34: 2427-2437. DOI: https://doi.org/ $10.1002 /$ joc. 3848

De la Riva EG, Olmo M, Poorter H, Ubera JL, Villar R. 2016. Leaf mass per area (LMA) and its relationship with leaf structure and anatomy in 34 Mediterranean woody species along a water availability gradient. PLOS ONE 11: e0148788. DOI: https://doi.org/10.1371/ journal.pone. 0148788

Dray S, Legendre P, Peres-Neto PR. 2006. Spatialmodelling: a comprehensive framework for principal coordinate analysis of neighbor matrices (PCNM). Ecological Modelling 196: 483-493. DOI: https://doi.org/ 10.1016/j.ecolmodel.2006.02.015

ESRI [Environmental Systems Research Institute]. 1999. Arcview GIS 3.3. Environmental Systems Research Institute, Redlands.

Fitzpatrick MC, Keller SR. 2015. Ecological genomics meets community-level modelling of biodiversity: Mapping the genomic landscape of current and future environmental adaptation. Ecology Letters 18: 1-16. DOI: https://doi.org/10.1111/ele.12376

Flexas J, Díaz-Espejo A, Gago J, Gallé A, Galmés J, Gulías J, Medrano H. 2014. Photosynthetic limitations in Mediterranean plants: A review. Environmental and Experimental Botany 103: 12-23. DOI: https://doi.org/ 10.1016/j.envexpbot.2013.09.002

García-Nogales A, Linares JC, Laureano RG, Seco JI, Merino J. 2016. Range-wide variation in life-history phenotypes: spatiotemporal plasticity across the latitudinal gradient of the evergreen oak Quercus ilex. Journal of Biogeography 43: 2366-2379. DOI: https:// doi.org/10.1111/jbi.12849

Gil-Pelegrín E, Saz MA, Cuadrat JM, Peguero-Pina JJ, Sancho-Knapik D. 2017. Oaks under Mediterranean-type climates: functional response to summer aridity. In: GilPeregrin E, Peguero-Pina JJ, Sancho-Knapik D, eds. Oaks Physiologycal Ecology. Exploring the functional diversity of genus Quercus L. eISBN 978-3-319-69099-5

Hernández-Calderón E, González-Rodríguez A, MéndezAlonzo R, Vega-Peña E, Oyama K. 2013. Contrasting leaf phenology in two white oaks, Quercus magnoliifolia and Quercus resinosa, along an altitudinal gradient in Mexico. Canadian Journal of Forest Research 43: 208-213. DOI: https://doi.org/10.1139/cjfr-2012-0406

Hernández-Calderón E, Méndez-Alonzo R, Martínez-Cruz J, González-Rodríguez A, Oyama K. 2014. Altitudinal changes in tree leaf and stem functional diversity in a semi-tropical mountain. Journal of Vegetation Science 25: 955-966. DOI: https://doi.org/10.1111/jvs.12158
Herrera-Arroyo ML, Sork VL, González-Rodríguez A, Rocha-Ramírez V, Vega E, Oyama K. 2013. Seedmediated connectivity among fragmented populations of Quercus castanea (Fagaceae) in a Mexican Landscape. American Journal of Botany 100: 1663-1671. DOI: https://doi.org/10.3732/ajb.1200396

Lavorel S, Díaz S, Cornelisse JHC, Urcelay C. 2007. Plant functional types: are we getting any closer to the Holy Grail? In: Canadell J, Pitelka LF, Pataki D, eds. Terrestrial Ecosystems in a Changing World. Berlin: Springer-Verlag. pp 149-164. DOI: https:// doi.org/10.1007/978-3-540-32730-1_13; eISBN 978-3540-32730-1

Lind BM, Friedline CJ, Wegrzyn JL, Maloney PE, Vogler DR, Neale DB, Eckert AJ. 2017. Water availability drives signatures of local adaptation in whitebark pine (Pinus albicaulis Engelm.) across fine spatial scales of the Lake Tahoe Basin, USA. Molecular Ecology 26: 3168-3185. DOI: https://doi.org/10.1111/mec. 14106

Lohbeck M, Poorter L, Lebrija-Trejos E, Martínez-Ramos M, Meave JA, Paz H, Pérez-García EA, Romero-Pérez IE, Tauro A, Bongers F. 2013. Successional changes in functional composition contrast for dry and wet tropical forest. Ecology 94: 1211-1216. DOI: https://doi.org/ $\underline{10.1890 / 12-1850.1}$

Manel S, Gugerli F, Thuiller W, Alvarez N, Legendre P, Holdereger R, Gielly L, Taberlet P, IntraBioDiv Consortium. 2012. Broad-scale adaptive genetic variation in alpine plants is driven by temperature and precipitation. Molecular Ecology 21: 3729-3738. DOI: https://doi.org/10.1111/j.1365-294X.2012.05656.x

Markwell J, Osterman JC, Mitchell JL. 1995. Calibration of the Minolta SPAD-502 leaf chlorophyll meter. Photosynthesis Research 46: 467-472. DOI: https:// doi.org/10.1007/BF00032301

McKnow AD, Guy RD, Klápste J, Geraldes A, Friedmann M, Cronk QCB, El-Kassaby YA, Mansfield SD, Douglas CJ. 2014. Geographical and environmental gradients shape phenotypic trait variation and genetic structure in Populus trichocarpa. New Phytologist 201: 1263-1276. DOI: https://doi.org/10.1111/nph.12601

Meireles JE, Beulke A, Borkowski DS, Romero-Severson J, Cavender-Bares J. 2017. Balancing selection maintains diversity in a cold tolerance gene in broadly distributed live oaks. Genome 60: 762-769. DOI: https://doi.org/ $\underline{10.1139 / \text { gen-2016-0208 }}$

Mendoza ME, Bocco G, Bravo M, López-Granados E, Osterkamp WR. 2006. Predicting water-sur face fluctuation of continental lakes: ARS and GIS based 
approach in central Mexico. Water Resources Management 20: 291-311. DOI: http://dx.doi.org/ $\underline{10.1007 / \mathrm{s} 11269-006-8199-\mathrm{z}}$

Niinemets Ü. 2001. Global-scale climatic controls of leaf dry mass per area, density, and thickness in trees and shrubs. Ecology 82: 453-469. DOI: https://doi.org/ 10.1890/0012-9658(2001)082[0453:GSCCOL]2.0.CO;2

Oksanen J, Blanchet FG, Kindt R, Legendre P, Minchin PR, O'Hara RB, Simpson GL, Solymos P, Stevens MHH, Wagner H. 2015. Vegan: Community Ecology Package. R package V2.2-1. http://www.pelagicos.net/ MARS6910_spring2015/manuals/R_vegan.pdf

Oyama K, Herrera-Arroyo ML, Rocha-Ramírez V, BenítezMalvido J, Ruiz-Sánchez E, González-Rodríguez A. 2017. Gene flow interruption in a recently humanmodified landscape: The value of isolated trees for the maintenance of genetic diversity in a Mexican endemic red oak. Forest Ecology and Management 390: 27-35. DOI: https://doi.org/10.1016/j.foreco.2017.01.018

Peguero-Pina JJ, Sisó S, Fernández-Marín B, Flexas J, Galmés J, García-Plazaola JI, Niinemets Ü, SanchoKnapik D, Gil-Peregrin E. 2016. Leaf functional plasticity decreases the water consumption without further consequences for carbon uptake in Quercus coccifera L. under Mediterranean conditions. Tree Physiology 36: 356-367. DOI: https://doi.org/10.1093/ treephys/tpv129

Peres-Neto PR, Legendre P, Dray S, Borcard D. 2006. Variation partitioning of species data matrices: Estimation and comparison of fractions. Ecology 87: 2614-2625. DOI: https://doi.org/10.1890/00129658(2006)87[2614:VPOSDM]2.0.CO;2

Petit RJ, Carlson J, Curtu AL, Loustau ML, Plomion C, González-Rodríguez A, Sork V, Ducousso A. 2013. Fagaceae trees as models to integrate ecology, evolution and genomics. New Phytologist 197: 369-371. DOI: https://doi.org/10.1111/nph.12089

Poorter H, Niinemets Ü, Poorter L, Wright IJ, Villar R. 2009. Causes and consequences of variation in leaf mass per area (LMA): a meta-analysis. New Phytologist 182: 565-588. DOI: https://doi.org/10.1111/ j.1469-8137.2009.02830.x

R Core Team 2016. R: A language and environment for statistical computing. R Foundation for Statistical Computing, Vienna, Austria. $<\underline{\text { https://www.R- }}$ project.org/>

Ramírez-Valiente JA, Sánchez-Gómez D, Aranda I, Valladares F. 2010. Phenotypic plasticity and local adaptation in leaf ecophysiological traits of 13 contrasting cork oak populations under different water availabilities. Tree Physiology 30: 618-627. DOI: https:// doi.org/10.1093/treephys/tpq013

Ramírez-Valiente JA, Valladares F, Delgado A, Nicotra AB, Aranda I. 2015. Understanding the importance of intrapopulation functional variability and phenotypic plasticity in Quercus suber. Tree Genetics \& Genomes 11: 35. DOI: https://doi.org/10.1007/s11295-015-0856-z

Ramírez-Valiente JA, Center A, Sparks JP, Sparks KL, Etterson JR, Longwell T, Pilz G, Cavender-Bares J. 2017. Population-level differentiation in growth rates and leaf traits in seedlings of the neotropical live oak Quercus oleoides grown under natural and manipulated precipitation regimes. Frontiers in Plant Science 8: 585. DOI: https://doi.org/10.3389/fpls.2017.00585

Rasband WS. 2010. ImageJ. Bethesda, Maryland, USA. National Institutes of Health. https://imagej.nih.gov/ij/ (Accessed April 7, 2015).

Rosbakh S, Römermann C, Poschlod P. 2015. Specific leaf area correlates with temperature: new evidence of trait variation at the population, species and community levels. Alpine Botany 125: 79-86. DOI: https://doi.org/ 10.1007/s00035-015-0150-6

Souto C, Premoli A, Reich P. 2009. Complex bioclimatic and soil gradients shape leaf trait variation in Embothrium coccineum (Proteaceae) among austral forest in Patagonia. Revista Chilena de Historia Natural 82: 209-222. DOI: https://doi.org/10.4067/ S0716-078X2009000200004

Tyree MT, Dixon MA. 1986. Water stress induced cavitation and embolism in some woody plants. Physiologia Plantarum 66: 397-405. DOI: https:// doi.org/10.1111/j.1399-3054.1986.tb05941.x

Tyree MT, Ewers FW. 1991. The hydraulic architecture of trees and other woody plants. New Phytologist 119: 345-360. DOI: https://doi.org/10.1111/j.1469-8137.1991. $\underline{\text { tb00035.x }}$

Uribe-Salas D, Sáenz-Romero C, González-Rodríguez A, Téllez-Valdéz O, Oyama K. 2008. Foliar morphological variation in the white oak Quercus rugosa Née (Fagaceae) along a latitudinal gradient in Mexico: Potential implications for management and conservation. Forest Ecology and Management 256: 2121-2126. DOI: https://doi.org/10.1016/j.foreco.2008.08.002

Valencia-A S. 2004. Diversidad del género Quercus (Fagaceae) en México. Boletín de la Sociedad Botánica de México 75: 33-53. DOI: https://doi.org/10.17129/ botsci. 1692

Valencia-Cuevas L, Mussali-Galante P, Piñero D, CastilloMendoza E, Rangel-Altamirano G, Tovar-Sánchez E. 2015. Hybridization of Quercus castanea (Fagaceae) across a red oak species gradient in Mexico. Plant 
Systematics and Evolution 301: 1085-1097. DOI: https:// doi.org/10.1007/s00606-014-1151-4

Van den Wollenberg AL. 1977. Redundancy analysis: an alternative for canonical analysis. Psychometrika 42: 207-219. DOI: https://doi.org/10.1007/BF02294050

Westoby M, Falser DS, Moles AT, Vesk PA, Wright IJ. 2002. Plant ecological strategies: some leading dimensions of variation between species. Annual Review of Ecology and Systematics 33: 125-159. DOI: https:// doi.org/10.1146/annurev.ecolsys.33.010802.150452

\section{Associate Editor: Miguel Olvera Vargas}

Author contribution: LILC conceived the idea, designed the study, performed field work, analyzed the data and wrote the manuscript; FGO supervised the design of the study, the data analysis and the preparation of the manuscript; KO obtained funding and supervised the manuscript preparation; AGR supervised the design of the study, data analysis and manuscript preparation, participated in the field work and obtained funding; all authors contributed to the review and approval of the manuscript.
Wright IJ, Reich PB, Westoby M, Ackerly DD, Baruch Z, Bongers $\mathrm{F}$, Cavender-Bares J, Chapin T, Cornelissen JHC, Diemer M, Flexas J, Garnier E, Groom PK, Gulias J, Hikosaka K, Lamont BB, Lee T, Lee W, Lusk C, Midgle J, Navas ML, Niinemets Ü, Oleksyn J, Osada N, Poorter H, Poot P, Prior L, Pyankov VI, Roumet C, Thomas SC, Tjoelker MG, Veneklas EJ, Villar R. 2004. The worldwide leaf economics spectrum. Nature 428: 621-827. DOI: https://doi.org/10.1038/nature02403 